\title{
Efficiency Measurement of Regional Development Agencies in Turkey by Using Data Envelopment Analysis (DEA)
}

\section{Recep TARI $^{1} \quad$ Ferhat PEHLIVANOĞLU $^{2} \quad$ Mehmet ÖZBÍLGIN $^{3}$}

\begin{abstract}
In this study, relative efficiencies of Regional Development Agencies (RDA) work in Turkey were determined using Data Envelopment Analysis (DEA). The goal of DEA is to measure relative efficiencies of comparable Decision Making Units which produce similar input and output. At the end of the analysis, reference decision making units will be determined for inefficient decision making units. To do this data are gathered from efficiency reports of Regional Development Agencies and based on these data, efficiency scores are calculated. At the end of the study, recommendations are given with the help of findings to improve RDAs performances.
\end{abstract}

Keywords: Regional Development, Regional Development Agencies, Efficiency, Data Envelopment Analysis, CCR Model, BCC Model.

JEL Classification Codes: C21, D24, D61, L25.

\section{Veri Zarflama Analiziyle Türkiye'deki Bölgesel Kalkınma Ajanslarının Etkinliğinin Ölçülmesi}

\section{$\ddot{O} z$}

Bu çalışmada Veri Zarflama Analizi (VZA) kullanılarak Türkiye’deki Bölgesel Kalkınma Ajanslarının (BKA) göreli performansları karşılaştırılmıştır VZA'nın amacı, benzer girdilerle benzer çıtıtılar üreten karşılaştırılabilir karar birimlerinin göreli etkinliklerini ölçmektir. Analiz sonucunda etkin olmayan karar birimleri için referans olacak karar birimleri belirlenmektedir.. Etkinlik skorları BKA tarafindan yayınlanan faaliyet raporları baz alınarak hesaplanmıştır. Çalışmanın sonucunda, elde edilen bulgulardan yola çıkarak BKA'nın performansının nasıl artırılabileceğine yönelik öneriler sunulmuştur.

Anahtar Sözcükler: Bölgesel Kalkınma, Bölgesel Kalkınma Ajanslarl, Etkinlik, Veri Zarflama Analizi, CCR Modeli, BCC Modeli.

JEL Sinıflandırma Kodları: C21, D24, D61, L25.

\footnotetext{
1 Prof.Dr., Kocaeli Üniversitesi, İktisadi ve İdari Bilimler Fakültesi, İktisat Bölümü, rtari@kocaeli.edu.tr

${ }^{2}$ Doç.Dr., Kocaeli Üniversitesi, İktisadi ve İdari Bilimler Fakültesi, İktisat Bölümü, fpehlivanoglu@kocaeli.edu.tr

3 Araş.Gör., Kocaeli Üniversitesi, İktisadi ve İdari Bilimler Fakültesi, İktisat Bölümü, mehmetozbilgin@yahoo.com
} 


\section{R.TARI -F.PEHLIVANOĞLU -M.ÖZBİLGİN \\ 1. INTRODUCTION}

There has been transformation in the field of regional development with the help of changes occurred during production and globalization processes. As a result, instead of national development regional development policy started to appear. (Keating, 2004; Stimson et al. 2006) Europe led the change along with some other countries which are developing regional competitions and giving more and more importance on regional economies. (Bachtler and Yuill, 2001; Ansell, 2000) Every region has different needs related to its condition thus, policy development effort to cater for every need of the regions is acknowledged as a strategy to trigger inner potential. (Maillat, 1998, p. 119) It has been proposed that national development will gain speed as results of reformation of regional development policies so that regions improve capacities and local resources and they will compete with each other. (Rao and Babu, 1996, p. 96) As a result, difference in socio-cultural and economic aspects in local created a path to new regional development tools which focus on regional needs and resources (Halkier et al., 1998, p. 45), and this made the way for key people play a more efficient role on decision-making processes.

Development agencies, considered as new and important tool for regional development. They are organizational forms that brought about as a result of new perspectives and with the efforts of institutionalization in the field of regional development. Agencies financial expenditures are fulfilled by government and private sector institutions. Agencies represents many people and are created based on laws and carries independent or semi-independent unit properties. (Mountford, 2009) On the other hand, according to The European Association of Development Agencies (EURADA) development agencies are units which focuses on problems in field of either sectoral or general and develops tools to solve these problems in order to improve region's social and economic problems and supports regional development projects. (EURADA, 1999)

Turkey also adopted a new regional development approach with process of becoming a member of EU in which regional competition gains importance and 
regions start to improve their capacities and inner dynamics are triggered. (DDK, 2014, p. 771). According to this approach regional planning must be dealt with a new perspective and tools need to be recycled. It considers not only potential of underdeveloped regions but potential of all regions and it focuses on determining policy tools which contribute to increasing regional competitive advantages.

Turkey's efforts to increase global competition power and extent of developmental level differences among regions gave priority to forming of regional policy and development strategies. Thus, need for agents and tools to provide regional competitiveness brought out idea of establishing regional development agencies. In connection with this, parallel to developments all around the world, since 2006 Turkey has been establishing RDAs. Even though long time has passed since establishing of RDAs there are still differences between countryside and cities in terms of developmental level so that speeding up regional development continues to be one of the priorities. From this point of view, RDAs have been established in order to create regional competitiveness however, success rate of development agencies in facilitating competition among regions and contributing to Turkey's economy has been a debate topic.

Development agencies are considered as regional economical development tool. The function they are expected to fulfill and contributions of operations they carry out to the region are closely connected with the ability of qualified production and efficiency level. The goal of this study is to compare efficiencies of 26 RDAs in Turkey and determining input and output targets for inefficient agencies to help them improve their performances.

In the following chapters of this study, firstly Data Envelopment Analysis (DEA) theory is reviewed, then findings are introduced which were found according to performances of agencies related to income status according to constant and variable scale. 26 operating regional development agencies in Turkey are listed below: 


\section{R.TARI -F.PEHLIVANOĞLU -M.ÖZBİLGİN}

Table 1. Development Agencies in Turkey

\begin{tabular}{|c|c|c|}
\hline Region & Cities & Regional Development Agencies \\
\hline TR10 & Istanbul & Istanbul Development Agency \\
\hline TR21 & Tekirdağ, Edirne, Kırklareli & Trakya Development Agency \\
\hline TR22 & Balıkesir, Çanakkale & Güney Marmara Development Agency \\
\hline TR31 & Izmir & Izmir Development Agency \\
\hline TR32 & Aydın, Denizli, Muğla & Güney Ege Development Agency \\
\hline TR33 & Manisa, Afyon, Kütahya, Uşak & Zafer Development Agency \\
\hline TR41 & Bursa, Eskişehir, Bilecik & $\begin{array}{l}\text { Bursa Eskişehir Bilecik Development } \\
\text { Agency }\end{array}$ \\
\hline TR42 & Kocaeli, Sakarya, Düzce, Bolu,Yalova & Dogu Marmara Development Agency \\
\hline TR51 & Ankara & Ankara Development Agency \\
\hline TR52 & Konya, Karaman & Mevlana Development Agency \\
\hline TR61 & Antalya, Isparta, Burdur & Batı Akdeniz Development Agency \\
\hline TR62 & Adana, Mersin & Çukurova Development Agency \\
\hline TR63 & Hatay, Kahramanmaraş, Osmaniye & Dogu Akdeniz Development Agency \\
\hline TR71 & $\begin{array}{l}\text { Kırıkkale, Aksaray, Niğde,Nevşehir, } \\
\text { Kırşehir }\end{array}$ & Ahiler Development Agency \\
\hline TR72 & Kayseri, Sivas, Yozgat & Orta Anadolu Development Agency \\
\hline TR81 & Zonguldak, Karabük, Bartın & Batı Karadeniz Development Agency \\
\hline TR82 & Kastamonu, Çankırı, Sinop & Kuzey Anadolu Development Agency \\
\hline TR83 & Samsun, Tokat, Çorum, Amasya & Orta Karadeniz Development Agency \\
\hline TR90 & $\begin{array}{l}\text { Trabzon, Ordu, Giresun, Rize, Artvin, } \\
\text { Gümüşhane }\end{array}$ & Dogu Karadeniz Development Agency \\
\hline TRA1 & Erzurum, Erzincan, Bayburt & $\begin{array}{lll}\text { Kuzeydogu Anadolu } & \text { Development } \\
\text { Agency } & & \\
\end{array}$ \\
\hline TRA2 & Ağrı, Kars, Iğdır, Ardahan & Serhat Development Agency \\
\hline TRB1 & Malatya, Elazı $\breve{g}$, Bingöl, Tunceli & Firat Development Agency \\
\hline TRB2 & Van, Muş, Bitlis, Hakkari & Doğu Anadolu Development Agency \\
\hline TRC1 & Gaziantep, Adıyaman, Kilis & Ipekyolu Development Agency \\
\hline TRC2 & Şanlıurfa, Diyarbakır & Karacadağ Development Agency \\
\hline Region & Cities & Regional Development Agencies \\
\hline TRC3 & Mardin, Batman, Şırnak, Siirt & Dicle Development Agency \\
\hline
\end{tabular}

\section{DATA ENVELOPMENT ANALYSIS}

Based on the work of Farrell (1957), DEA is known as a nonparametric mathematical model and linear programming technique to analyze efficiency. The return of this approach over parametric methods (i.e. regression) is that no assumptions are needed regarding the relationship between the inputs and outputs. Thus, complex or ambiguous relationships can still be modeled (Sadiq, 2011). 
The goal is to measure relative performances of production units, which are assumed to be homogenous in DEA, and to make comparison among them. By weighting input/output rate the most, efficiency of Decision Making Units is tried to be made maximum. (Charnes et al., 1978) From this aspect, division of weighted sum of outputs to weighted sum of inputs is accepted as a basic criterion for efficiency. DEA provides a relative efficiency score for each decision making unit. As a result of the analysis, it is clear that group which consumes less input and produces more output considered as efficient; conversely, if group consumes more and produces less, it is considered as inefficient. Relative efficiency is defined as the ratio of total weighted sum of outputs to the weighted sum of inputs. (Adler et al., 2002)

Efficiency $=$ weighted sum of outputs / weighted sum of inputs

Efficiency score, which is ratio of weighted sum of outputs to weighted sum of inputs, can be 1 at most. Decision making units that have score of 1 are considered as efficient. Inefficient units have score in a range from 0 to 1 relatively.

CCR model was developed by Charnes, Cooper and Rhodes and BCC model was developed by Charnes \& Cooper and they are used widely in literature. CCR model is based on constant return assumption to scale. However, BCC model is based on variable return assumption to scale.

There are two types of approaches in DEA input oriented and output oriented; input oriented is to get the most output with the determined input and output oriented is to determine the least amount of needed input for efficiently producing expected output. Input-oriented models investigate how much of the input can be reduced while output is constant. On the other hand, output oriented models investigate how much of output can be increased by keeping input constant.

\subsection{CCR Model}

The relative efficiency score of $\mathrm{j}_{0}$ DMU with $\mathrm{m}$ different inputs and s outputs is given by solving the following DEA ratio model (CCR) proposed by Charnes et al. (1978). Efficiency in DEA is defined as the ratio of total weighted output to total 


\section{R.TARI -F.PEHLIVANOĞLU -M.ÖZBİLGIN}

weighted input. By comparing $n$ units with $s$ outputs denoted by $\mathrm{y}_{\mathrm{rj}} ; \mathrm{r}=1, \ldots, \mathrm{s}$, and $\mathrm{m}$ inputs denoted by $\mathrm{x}_{\mathrm{ij}}, \mathrm{i}=1, \ldots, \mathrm{m}$, the mathematical form is shown below. The basic mathematical formulation of the relative efficiency score of $j_{0}$ DMU has the following form:

$$
\max h_{j o}=\frac{\sum_{r=1}^{s} u_{r} y_{r_{j 0}}}{\sum_{i=1}^{m} v_{i} x_{i_{j 0}}}
$$

$h_{j 0}$ is the DEA relative efficiency measure. The weights, $u_{r}$ and $v_{i}$, are nonnegative. Here, $\mathrm{x}_{\mathrm{ij}} \geq 0$ parameter shows $\mathrm{i}$ input amount used by $\mathrm{j}$ decision unit, and $\mathrm{y}_{\mathrm{rj}}>0$ parameter shows $\mathrm{r}$ output amount used by $\mathrm{j}$ decision unit. It is referred to as $D M U_{j}$ in a collection of $j=1, \ldots, n$ entities which utilize these $i=1, \ldots, m$ inputs and produce these $\mathrm{r}=1, \ldots, \mathrm{s}$ outputs (Bowlin, 1998: 5). Symbols, used in model, are defined as below:

$$
\begin{aligned}
& \mathrm{n}=\text { Number of DMU }\{j=1,2, \ldots, \mathrm{n}\} \\
& \mathrm{s}=\text { Number of outputs }\{\mathrm{r}=1,2, \ldots, \mathrm{s}\} \\
& \mathrm{m}=\text { Number of inputs }\{\mathrm{i}=1,2, \ldots, \mathrm{m}\} \\
& \mathrm{y}_{\mathrm{rj}}=\text { Quantity of } \mathrm{r}^{\text {th }} \text { output of } \mathrm{j}^{\text {th }} \mathrm{DMU} \\
& \mathrm{x}_{\mathrm{ij}}=\text { Quantity of } \mathrm{i}^{\text {th }} \text { input of } \mathrm{j}^{\text {th }} \mathrm{DMU} \\
& \mathrm{u}_{\mathrm{r}}=\text { weight } \text { of } \mathrm{r}^{\text {th }} \text { output } \\
& \mathrm{v}_{\mathrm{i}}=\text { weight of } \mathrm{i}^{\text {th }} \text { input }
\end{aligned}
$$

The ratio of weighted sum of output to weighted sum of input is equal to 1 or smaller than 1 . This is the first defined constraint:

$$
\frac{\sum_{r=1}^{S} u_{r} y_{r j}}{\sum_{i=1}^{m} v_{i} x_{i j}} \leq 1 \text { for each unit } j
$$


$\frac{u_{r}}{\sum_{i=1}^{m} v_{i} x_{i_{0}}}>\varepsilon$

$\frac{v_{i}}{\sum_{i=1}^{m} v_{i} x_{i_{0}}}>\varepsilon \varepsilon>0$

The $\mathcal{E}$ represents a non-archimedean constant which is smaller than any positive valued real number. The second constraint prevents used input and output to be negative is given below:

$u_{r}, v_{i} \geq 0$

\subsubsection{Input-Oriented CCR Model}

Input-oriented CCR model investigates combination of the least input for determined level of output. Eq. (2) is the ratio form of DEA. This fractional programming model can be converted to a linear programming problem (Bowlin, 1998: 7). Model that is formed after transformation known as "Charnes-Cooper Transformation" is given below:

$$
\max h_{j 0}=\sum_{r=1}^{s} u_{r} y_{r j}
$$

In fractional function denominator of aim function is equated to 1 in transformation.

$$
\text { subject to } \sum_{i=1}^{m} v_{i} x_{i j_{0}}=1
$$

$\sum_{r=1}^{s} u_{r} y_{r j}-\sum_{i=1}^{m} v_{i} x_{i j_{0}} \leq 0 \quad j=1,2, \ldots, n$

$u_{r}, v_{i} \geq 0 \forall r, i ; \quad-u_{r} \leq-\varepsilon ; \quad-v_{i} \leq-\varepsilon$

It is hard to determine reference decision units in fractional and linear programming models. For this reason, envelopment model is formed by taking the dual of weighted model above:

$$
\text { minimize: } \theta-\varepsilon\left[\sum_{i=1}^{m} s_{i}{ }^{-}+\sum_{r=1}^{S} s_{r}{ }^{+}\right]
$$




\section{R.TARI -F.PEHLIVANOĞLU -M.ÖZBİLGINN}

subject to: $0=\theta x_{i_{0}}-\sum_{j=1}^{n} x_{i j} \lambda_{j}-s_{i}$

$y_{r 0}=\sum_{j=1}^{n} y_{r j} \lambda_{j}-s_{r}+$

$$
0 \leq \lambda_{j}, s_{i}{ }^{-}, s_{r}{ }^{+} \text {for } \mathrm{i}=1, \ldots, \mathrm{m} ; \quad \mathrm{r}=1, \ldots, \mathrm{s} ; \mathrm{j}=1, \ldots, \mathrm{n}
$$

In dual model weights on DMU, “ $\lambda_{j}$ ” is calculated instead of weights on input and output. Thus, $\lambda$ variable is used for determining efficient reference sets.

\subsubsection{Output-Oriented CCR Model}

$\mathrm{CCR}$ is another model which is used to produce maximum amount of output with determined input level. Linear programming model for output oriented case is given below:

$$
\begin{aligned}
& \min h_{j 0}=\sum_{i=1}^{m} v_{i} x_{i j_{0}} \\
& \text { subject to }-\sum_{r=1}^{s} u_{r} y_{r j}+\sum_{i=1}^{m} v_{i} x_{i j} \geq 0 \\
& j=1,2, \ldots, n \\
& \sum_{r=1}^{s} u_{r} y_{i j_{0}}=1 \\
& \mathrm{r}=1, \ldots, \mathrm{s} ; \mathrm{i}=1, \ldots, \mathrm{m}
\end{aligned}
$$

Envelopment model is formed by taking dual of weighted output oriented model above:

$$
\text { maximize: } \beta-\varepsilon\left[\sum_{i=1}^{m} s_{i}{ }^{-}+\sum_{r=1}^{s} s_{r}{ }^{+}\right]
$$

subject to: $0=x_{i_{0}}-\sum_{j=1}^{n} x_{i j} \lambda_{j}-s_{i}^{-}$

$$
\begin{aligned}
& \beta y_{r 0}=\sum_{j=1}^{n} y_{r j} \lambda_{j}-s_{r}{ }^{+} \\
& 0 \leq \lambda_{j}, s_{i}{ }^{-}, s_{r}{ }^{+} \text {for } \mathrm{i}=1, \ldots, \mathrm{m} ; \quad \mathrm{r}=1, \ldots, \mathrm{s} ; \quad \mathrm{j}=1, \ldots, \mathrm{n}
\end{aligned}
$$




\subsection{BCC Model}

Another version of DEA, which is used commonly, is the Banker, Charnes, and Cooper (BCC) (1984) model. They have upgraded the model suggested by Banker et al. (1984), Charnes et al. (1978) to make it match with variable returns assumption to scale.

The main distinction between the BCC and the CCR model is the treatment of returns to scale. The CCR version bases the evaluation on constant returns to scale. The BCC version is more flexible and allows variable returns to scale (Bowlin, 1998: 8).

\subsubsection{Input-Oriented BCC Model}

Input-oriented BCC primal linear programming problem is depicted below (Banker et al., 1984: 1085):

maximize: $\sum_{r=1}^{s} u_{r} y_{r 0}-u_{0}$

subject to: $\sum_{r=1}^{s} u_{r} y_{r j}-\sum_{i=1}^{m} v_{i} x_{i j}-u_{0} \leq 0$

$\sum_{i=1}^{m} v_{i} x_{i_{0}}=1$

$v_{i}, u_{r} \geq \varepsilon ; \quad u_{0}$ free in sign.

The above formulations assume that $x_{i j}, y_{\mathrm{rj}} \geq 0 \forall \mathrm{i}, \mathrm{r}, \mathrm{j}$. The dual form of the (BCC) model, is presented in (10):

$$
\begin{aligned}
& \text { minimize: } \theta-\varepsilon\left[\sum_{i=1}^{m} s_{i}{ }^{-}+\sum_{r=1}^{s} s_{r}{ }^{+}\right] \\
& \text {subject to: } 0=\theta x_{i_{0}}-\sum_{j=1}^{n} x_{i j} \lambda_{j}-s_{i}{ }^{-} \\
& y_{r 0}=\sum_{j=1}^{n} y_{r j} \lambda_{j}-s_{r}{ }^{+} \\
& \sum_{j=1}^{n} \lambda_{j}=1
\end{aligned}
$$




$$
\begin{aligned}
& \text { R.TARI -F.PEHLIVANOĞLU -M.ÖZBİLGIN } \\
& 0 \leq \lambda_{j}, s_{i}{ }^{-}, s_{r}{ }^{+} \text {for } \mathrm{i}=1, \ldots, \mathrm{m} ; \quad \mathrm{r}=1, \ldots, \mathrm{s} ; \quad \mathrm{j}=1, \ldots, \mathrm{n} \\
& \theta \text { and } \lambda \mathrm{j} \text { are dual variables; } \mathrm{s}^{-} \text {and } \mathrm{s}^{+} \text {are slack variables. }
\end{aligned}
$$

\subsubsection{Output-Oriented BCC Model}

The formulation for these BCC model is presented in (11) (Tone, 1996: 610):

minimize: $\sum_{i=1}^{m} v_{i} x_{i 0}-v_{0}$

subject to: $-\sum_{r=1}^{s} u_{r} y_{r j}+\sum_{i=1}^{m} v_{i} x_{i j}-v_{k} \geq 0$

$\sum_{r=1}^{s} u_{r} y_{i j_{0}}=1$

$u_{r} \geq \varepsilon, \quad v_{i} \geq \varepsilon$

Envelopment model of output oriented BCC model is written as below:

$$
\text { maximize: } \beta+\varepsilon\left[\sum_{i=1}^{m} s_{i}{ }^{-}+\quad \sum_{r=1}^{s} s_{r}{ }^{+}\right]
$$

subject to: $0=x_{i_{0}}-\sum_{j=1}^{n} x_{i j} \lambda_{j}-s_{i}^{-}$

$\beta y_{r 0}=\sum_{j=1}^{n} y_{r j} \lambda_{j}-s_{r}+$

$$
\sum_{j=1}^{n} \lambda_{j}=1
$$

$0 \leq \lambda_{j}, s_{i}{ }^{-}, s_{r}{ }^{+}$for $\mathrm{i}=1, \ldots, \mathrm{m} ; \quad \mathrm{r}=1, \ldots, \mathrm{s} ; \quad \mathrm{j}=1, \ldots, \mathrm{n}$

Difference between BCC and CCR stems from convexity constraint. In BCC it is accepted that sum of $\lambda \mathrm{s}$ are equal to 1 . These $\lambda \mathrm{s}$ are calculated as the results of linear programming problem which will be solved for every decision unit. (Cooper et al., 2007) Furthermore, in CCR model, which does analysis with an assumption of variable returns to scale, line passes through origin but in BCC model it does not have to pass through origin. 


\section{CASE STUDY}

In this section of the study these will be discussed; introduction of method, selection of variables that take place in analysis, formation of data sets, application of data envelopment analysis and evaluation of results.

\subsection{Methodology}

In this study Data Envelopment Analysis (DEA) is used to evaluate obtained data. The study was carried out to relatively measure operational efficiencies of Turkish development agencies that have similar input-output structure and same goals. Efficiency measurement is done with the help of Win4DEAP computer program by using input and output oriented BCC and CCR Model.

\subsection{Selection of Input and Output}

Firstly, 26 Regional Development Agencies in Turkey were identified as decision units for DEA Model. In connection with the aim of this study analyses were done by using data belong to every agency. Data sets, used in the study, were taken from agencies' operation reports from the year 2013. There are hardly any studies related to research for the efficiency of Regional Development Agencies (RDA). Many input and output variable can be identified to be used in agency evaluation. However, limited data on the operation reports that agencies published formed a constraint on selecting variable.

Studies in different fields in Literature were reviewed and seven input and one output found on table 2 have been added to analysis.

Table 2. Input and Output Variables That Were Used in Efficiency Evaluation

\begin{tabular}{|l|l|}
\hline \multicolumn{1}{|c|}{ Inputs } & Outputs \\
\hline I1: Number of staff with a Bachelor's degree & O1: Number of supported projects \\
\hline I2: Number of staff with a Master's degree & \\
\hline I3: Supporting expenses of Projects and operations & \\
\hline I4: Number of published reports & \\
\hline I5: Number of meetings held & \\
\hline I6: Trainings given & \\
\hline I7: Participation to meetings and trainings & \\
\hline
\end{tabular}




\section{R.TARI -F.PEHLIVANOĞLU -M.ÖZBIILGIN}

\section{FINDINGS OF THE STUDY}

Before making efficiency analysis, correlation and definitive statistics belong to input and output used in research were analyzed. Summary statistics for data sets of case study are shown in table 3 .

Table 3. Summary Statistics over Input and Output Variables

\begin{tabular}{|l|c|c|c|c|c|c|c|c|}
\hline Variables & O1 & I1 & I2 & I3 & I4 & I5 & I6 & I7 \\
\hline Mean & 109.3077 & 17.03846 & 19.38462 & 26285387 & 23.23077 & 30.15385 & 49.88462 & 2941.077 \\
\hline Median & 97 & 18 & 20.5 & 12412592 & 15.5 & 13.5 & 41 & 2305.5 \\
\hline Maximum & 337 & 30 & 42 & $3.31 E+08$ & 73 & 209 & 181 & 12469 \\
\hline Minimum & 30 & 4 & 3 & 6897612 & 2 & 1 & 2 & 150 \\
\hline Std. Dev. & 58.95881 & 7.017012 & 8.471491 & 62533608 & 18.50256 & 45.03127 & 36.58123 & 2550.339 \\
\hline Observations & 26 & 26 & 26 & 26 & 26 & 26 & 26 & 26 \\
\hline
\end{tabular}

Moreover, in table 4 correlation between input and output is seen. It is clear that from this point of view analysis is based on reliable source since there is high correlation between neither inputs nor outputs. When correlation analysis values had been evaluated no changes were made on input and output variables.

Table 4. The Correlation between Input and Output

\begin{tabular}{|l|l|l|l|l|l|l|l|l|}
\hline & \multicolumn{1}{|c|}{ O1 } & \multicolumn{1}{|c|}{ I1 } & I2 & I3 & I4 & I5 & I6 & 7 \\
\hline O1 & 1 & & & & & & & \\
\hline $\mathbf{I 1}$ & -0.1759 & 1 & & & & & & \\
\hline $\mathbf{I 2}$ & 0.134056 & -0.54194 & 1 & & & & & \\
\hline $\mathbf{I 3}$ & 0.268511 & 0.009082 & -0.41759 & 1 & & & & \\
\hline $\mathbf{I 4}$ & 0.028203 & 0.120392 & 0.048408 & -0.14634 & 1 & & & \\
\hline $\mathbf{I 5}$ & 0.010166 & 0.04454 & -0.29428 & -0.06381 & 0.368946 & 1 & & \\
\hline $\mathbf{I 6}$ & -0.18485 & 0.097567 & -0.10169 & -0.02815 & 0.234067 & 0.054646 & 1 & \\
\hline I7 & 0.282179 & 0.049097 & 0.042494 & -0.0142 & 0.20149 & -0.21547 & 0.639526 & 1 \\
\hline
\end{tabular}

RDA's efficiency scores, obtained at the end of the analysis, are given in table 5. Averages values show arithmetic mean of agencies' efficiency scores. Agencies, which have efficiency scores equal to 1, are fully efficient. Rests of agencies' operations are interpreted positively as their scores approach to 1 . 
Dokuz Eylül Üniversitesi İktisadi ve İdari Bilimler Fakültesi Dergisi Cilt:32, Sayl:2, Yll:2017, ss. 47-78

Efficiency scores calculated at the end of the analyses can be different according to used DEA model. In addition to this, as it is observed in Table-4 input and output oriented efficiency scores, which are calculated based on constant return assumption to the scale, give the same results for all KVBs.

Agencies with an efficient result according to both input and output oriented CCR Model, are efficient according to BCC results as well. It is observed that at input oriented cases 5 development agencies work with a constant return to scale. On the other hand, 21 development agencies work with an increasing return to scale. agencies in regions TR10, TR41, TR52, TR63 and TR90 are efficient according to input and output oriented CCR model while agencies in regions TR10, TR21, TR22, TR41, TR52, TR61, TR63, TR71, TR81, TR83, TR90, TRA2, TRB1, TRB2, TRC1 and TRC3 are efficient according to input and output oriented BCC model.

Table 5. Efficiency scores of Agencies and Reference Sets

\begin{tabular}{|c|c|c|c|c|}
\hline \multirow{3}{*}{ RDA } & \multicolumn{4}{|c|}{ Scale Efficiency and Return Status to Scale } \\
\hline & \multicolumn{4}{|c|}{ Input-oriented } \\
\hline & $\begin{array}{c}\text { CCR } \\
\text { Efficiency } \\
\text { Score }\end{array}$ & $\begin{array}{c}\text { BCC Efficiency } \\
\text { Score }\end{array}$ & $\begin{array}{c}\text { Scale } \\
\text { Efficiency }\end{array}$ & Return to Scale \\
\hline TR10 & 1.000 & 1.000 & 1.000 & CRS \\
\hline TR21 & 0.789 & 1.000 & 0.789 & IRS \\
\hline TR22 & 0.510 & 1.000 & 0.510 & IRS \\
\hline TR31 & 0.213 & 0.938 & 0.228 & IRS \\
\hline TR32 & 0.392 & 0.974 & 0.403 & IRS \\
\hline TR33 & 0.654 & 0.977 & 0.670 & IRS \\
\hline TR41 & 1.000 & 1.000 & 1.000 & CRS \\
\hline TR42 & 0.423 & 0.794 & 0.533 & IRS \\
\hline TR51 & 0.780 & 0.863 & 0.904 & IRS \\
\hline TR52 & 1.000 & 1.000 & 1.000 & CRS \\
\hline TR61 & 0.844 & 1.000 & 0.844 & IRS \\
\hline TR62 & 0.707 & 0.877 & 0.807 & IRS \\
\hline
\end{tabular}


R.TARI -F.PEHLIVANOĞLU -M.ÖZBİLGİN

\begin{tabular}{|c|c|c|c|c|}
\hline TR63 & 1.000 & 1.000 & 1.000 & CRS \\
\hline TR71 & 0.483 & 1.000 & 0.483 & IRS \\
\hline TR72 & 0.595 & 0.908 & 0.656 & IRS \\
\hline TR81 & 0.792 & 1.000 & 0.792 & IRS \\
\hline TR82 & 0.591 & 0.991 & 0.596 & IRS \\
\hline TR83 & 0.702 & 1.000 & 0.702 & IRS \\
\hline TR90 & 1.000 & 1.000 & 1.000 & CRS \\
\hline TRA1 & 0.458 & 0.745 & 0.614 & IRS \\
\hline TRA2 & 0.567 & 1.000 & 0.567 & IRS \\
\hline TRB1 & 0.551 & 1.000 & 0.551 & IRS \\
\hline TRB2 & 0.381 & 1.000 & 0.381 & IRS \\
\hline TRC1 & 0.647 & 1.000 & 0.647 & IRS \\
\hline TRC2 & 0.579 & 0.930 & 0.623 & IRS \\
\hline TRC3 & 0.207 & 1.000 & 0.207 & IRS \\
\hline Avg. & 0.649 & 0.961 & 0.673 & \\
\hline \multirow[b]{2}{*}{ RDA } & \multicolumn{4}{|c|}{ Output-oriented } \\
\hline & $\begin{array}{c}\text { CCR } \\
\text { Efficiency } \\
\text { Score }\end{array}$ & $\begin{array}{c}\text { BCC Efficiency } \\
\text { Score }\end{array}$ & $\begin{array}{c}\text { Scale } \\
\text { Efficiency }\end{array}$ & Return to Scale \\
\hline TR10 & 1.000 & 1.000 & 1.000 & CRS \\
\hline TR21 & 0.789 & 1.000 & 0.789 & IRS \\
\hline TR22 & 0.510 & 1.000 & 0.510 & IRS \\
\hline TR31 & 0.213 & 0.219 & 0.976 & IRS \\
\hline TR32 & 0.392 & 0.825 & 0.476 & IRS \\
\hline TR33 & 0.654 & 0.853 & 0.767 & IRS \\
\hline TR41 & 1.000 & 1.000 & 1.000 & CRS \\
\hline TR42 & 0.423 & 0.430 & 0.985 & IRS \\
\hline TR51 & 0.780 & 0.796 & 0.980 & DRS \\
\hline TR52 & 1.000 & 1.000 & 1.000 & CRS \\
\hline TR61 & 0.844 & 1.000 & 0.844 & IRS \\
\hline TR62 & 0.707 & 0.767 & 0.922 & DRS \\
\hline TR63 & 1.000 & 1.000 & 1.000 & CRS \\
\hline TR71 & 0.483 & 1.000 & 0.483 & IRS \\
\hline
\end{tabular}


Dokuz Eylül Üniversitesi İktisadi ve İdari Bilimler Fakültesi Dergisi Cilt:32, Sayl:2, Yıl:2017, ss. 47-78

\begin{tabular}{|c|c|c|c|c|}
\hline TR72 & 0.595 & 0.607 & 0.981 & DRS \\
\hline TR81 & 0.792 & 1.000 & 0.792 & IRS \\
\hline TR82 & 0.591 & 0.659 & 0.897 & IRS \\
\hline TR83 & 0.702 & 1.000 & 0.702 & IRS \\
\hline TR90 & 1.000 & 1.000 & 1.000 & CRS \\
\hline TRA1 & 0.458 & 0.466 & 0.982 & DRS \\
\hline TRA2 & 0.567 & 1.000 & 0.567 & IRS \\
\hline TRB1 & 0.551 & 1.000 & 0.551 & IRS \\
\hline TRB2 & 0.381 & 1.000 & 0.381 & IRS \\
\hline TRC1 & 0.647 & 1.000 & 0.647 & IRS \\
\hline RDA & $\begin{array}{c}\text { CCR } \\
\text { Efficiency } \\
\text { Score }\end{array}$ & $\begin{array}{c}\text { BCC Efficiency } \\
\text { Score }\end{array}$ & $\begin{array}{c}\text { Scale } \\
\text { Efficiency }\end{array}$ & Return to Scale \\
\hline TRC2 & 0.579 & 0.602 & 0.961 & DRS \\
\hline TRC3 & 0.207 & 1.000 & 0.207 & IRS \\
\hline Avg. & 0.649 & 0.855 & 0.785 & \\
\hline
\end{tabular}

Scale efficiencies are calculated through division of efficiency results obtained via CCR model to the results obtained via BCC model. When scale efficiency scores are reviewed it is observed that agencies in regions TR10, TR41, TR52, TR63 and TR90 have services at suitable scale and the highest scale efficiency. TRC3 has the lowest efficiency score, 0,207 and cannot be considered as efficient. In Turkey average scale efficiency score is 0,673 for CCR and 0,785 for BCC. Average efficiency scores in Turkey for CCR 0,673 and for BCC 0,785. According to CCR \& BCC models $57 \%$ and $38 \%$ of 26 RDAs are below average.

In table 6 efficiency scores of agencies are shown separately according to both input and output oriented BCC models. Agency in region TRC3 has the lowest efficiency score, 0,207, according to input oriented CCR model while Agency in region TRA1 has the lowest efficiency score, 0,745, according to input oriented BCC model among 26 agencies. 


\section{R.TARI -F.PEHLIVANOĞLU -M.ÖZBİLGİN}

Table 6. Efficiency Scores and Efficiency Rankings of Agencies

\begin{tabular}{|c|c|c|c|c|c|c|c|c|}
\hline \multirow{2}{*}{ RDA } & \multicolumn{4}{|c|}{ Input-Oriented } & \multicolumn{4}{|c|}{ Output-Oriented } \\
\hline & CCR & Rank & BCC & Rank & CCR & Rank & BCC & Rank \\
\hline TR10 & 1.000 & 1 & 1.000 & 1 & 1.000 & 1 & 1.000 & 1 \\
\hline TR21 & 0.789 & 4 & 1.000 & 1 & 0.789 & 4 & 1.000 & 1 \\
\hline TR22 & 0.510 & 15 & 1.000 & 1 & 0.510 & 15 & 1.000 & 1 \\
\hline TR31 & 0.213 & 21 & 0.938 & 5 & 0.213 & 21 & 0.219 & 11 \\
\hline TR32 & 0.392 & 19 & 0.974 & 4 & 0.392 & 19 & 0.825 & 3 \\
\hline \multirow{2}{*}{ RDA } & \multicolumn{4}{|c|}{ Input-Oriented } & \multicolumn{4}{|c|}{ Output-Oriented } \\
\hline & CCR & Rank & BCC & Rank & CCR & Rank & BCC & Rank \\
\hline TR33 & 0.654 & 8 & 0.977 & 3 & 0.654 & 8 & 0.853 & 2 \\
\hline RDA & CCR & Rank & $\mathbf{B C C}$ & Rank & CCR & Rank & BCC & Rank \\
\hline TR41 & 1.000 & 1 & 1.000 & 1 & 1.000 & 1 & 1.000 & 1 \\
\hline TR42 & 0.423 & 18 & 0.794 & 10 & 0.423 & 18 & 0.430 & 10 \\
\hline TR51 & 0.780 & 5 & 0.863 & 9 & 0.78 & 5 & 0.796 & 4 \\
\hline TR52 & 1.000 & 1 & 1.000 & 1 & 1.000 & 1 & 1.000 & 1 \\
\hline TR61 & 0.844 & 2 & 1.000 & 1 & 0.844 & 2 & 1.000 & 1 \\
\hline TR62 & 0.707 & 6 & 0.877 & 8 & 0.707 & 6 & 0.767 & 5 \\
\hline TR63 & 1.000 & 1 & 1.000 & 1 & 1.000 & 1 & 1.000 & 1 \\
\hline TR71 & 0.483 & 16 & 1.000 & 1 & 0.483 & 16 & 1.000 & 1 \\
\hline TR72 & 0.595 & 10 & 0.908 & 7 & 0.595 & 10 & 0.607 & 7 \\
\hline TR81 & 0.792 & 3 & 1.000 & 1 & 0.792 & 3 & 1.000 & 1 \\
\hline TR82 & 0.591 & 11 & 0.991 & 2 & 0.591 & 11 & 0.659 & 6 \\
\hline TR83 & 0.702 & 7 & 1.000 & 1 & 0.702 & 7 & 1.000 & 1 \\
\hline TR90 & 1.000 & 1 & 1.000 & 1 & 1.000 & 1 & 1.000 & 1 \\
\hline TRA1 & 0.458 & 17 & 0.745 & 11 & 0.458 & 17 & 0.466 & 9 \\
\hline TRA2 & 0.567 & 13 & 1.000 & 1 & 0.567 & 13 & 1.000 & 1 \\
\hline TRB1 & 0.551 & 14 & 1.000 & 1 & 0.551 & 14 & 1.000 & 1 \\
\hline TRB2 & 0.381 & 20 & 1.000 & 1 & 0.381 & 20 & 1.000 & 1 \\
\hline TRC1 & 0.647 & 9 & 1.000 & 1 & 0.647 & 9 & 1.000 & 1 \\
\hline TRC2 & 0.579 & 12 & 0.930 & 6 & 0.579 & 12 & 0.602 & 8 \\
\hline TRC3 & 0.207 & 22 & 1.000 & 1 & 0.207 & 22 & 1.000 & 1 \\
\hline Ort. & 0.649 & & 0.961 & & 0.649 & & 0.855 & \\
\hline
\end{tabular}

Agency in region TRC3 has the lowest efficiency score, which is 0,207, according to output oriented CCR and agency in region TR31 has the lowest efficiency score, which is 0,219 , according to output oriented BCC model. 
According to input oriented CCR model agencies in regions TR61, TR81, TR21 and TR51 are the nearest ones to efficiency score with scores of 0,844, 0,792, 0,789, and 0,780 respectively. Agencies in regions TR82, TR33, TR32 and TR31 according to input oriented $\mathrm{BCC}$ are the nearest ones to efficiency score with scores $0,991,0,977,0,974$ and 0,938 respectively. Agencies in regions TR33, TR32, TR51 and TR62 according to output oriented BCC model, are the nearest ones to efficiency score with scores $0,853,0,825,0,796$ and 0,767 respectively.

Table-7 shows original and aimed values of input and output of agencies which do not have an efficiency score equal to 1 according to input oriented CCR model. Difference between current situation and aimed values describes remoteness of inefficient decision unit to efficiency verge. In addition, difference is are also shown on the table which signifies the amount of change needed to be made and potential improvement ratio for inefficient agencies to become efficient. Agencies can increase their efficiencies by taking those potential improvement ratios on the table into consideration. Only input oriented BCC values were studied due to unavailability of enough room.

When we analyze results in depth, for the agencies in region TR31, these are needed to be decreased accordingly; number of staff with a Bachelor's Degree (G1) from 12 to 11 with ratio of $6,6 \%$, number of staff with a Master's Degree (G2) from 31 to 2 with ratio of $32 \%$, project and operation supporting expenses (G3) from 11,2 Million Liras to 10,5 Million Liras with a ratio of $6 \%$, number of published reports (G4) from 11 to 10 with ratio of $9 \%$, number of meetings held (G5) from 14 to 13 with a ratio of $7 \%$, training programs given from 42 to 21 with a ratio of 50\%, attendance to meetings and trainings (G7) from 2.469 to 928 with a ratio of $62 \%$. On the other hand, number of supported projects $(\mathrm{C} 1)$ is needed to be increased from 41 to 95 with a ratio of $131 \%$.

For TR32; these should be decreased; G1 from 19 to 17, G2 from 21 to 15, G3 from 7.4 Million Liras to 7.2 Million Liras, G4 from 50 to 28, G6 from 42 to 32, G7 from 2.930 to 2.221; however, C1 should be increased from 69 to 74 . For TR33; these should be decreased accordingly; G3 from 1.7 Million Liras to 1.36 


\section{R.TARI -F.PEHLIVANOĞLU -M.ÖZBİLGIN}

Million Liras, G5 from 38 to 37, G6 from 59 to 34, G7 1.726 to 1.126; but, C1 should be the same. For TR42 these should be decreased; G1 from 11 to 9, G6 from 186 to 21, G7 from 12.469 to 1.792 ; on the other hand, C1 mustn't be changed. For TR51 these should be decreased; G1 from 18 to 16, G2 from 20 to 17, G3 from 1.7 Million Liras to 1.46 Million Liras, G4 from 27 to 11, G5 from 26 to 22 , G6 from 36 to 22 , G7 from 2.289 to 1.975 ; but C1 should stay same.

For TR62 these should be decreased; G1 from 19 to 13, G2 from 18 to 16, G3 from 2.56 Million Liras to 1.98 Million Liras, G4 from 11 to 4, G5 from 8 to 7, G6 from 35 to 17, G7 from 2.322 to 629; however $\mathrm{C} 1$ shouldn't be changed. For TR82 these should be decreased; G1 from 14 to 13, G2 from 27 to 21, G3 from 1.11 Million Liras to 1.10 Million Liras, G4 from 22 to 13, G5 from 6 to 2, G7 from 1.739 to 1.723 ; but $\mathrm{C} 1$ should be increased from 96 to 137 . For TRA1 these should be decreased; G1 from 19 to 14, G2 from 20 to 15, G3 from 15 Million Liras to 11 Million Liras, G4 from 55 to 25, G5 from 96 to 36, G6 from 50 to 37, G7 from 2.684 to 1.930; and C1 should be increased from 95 to 96 . For TRC2 these should be decreased accordingly; G1 from 23 to 15, G2 from 11 to 10, G3 from 32 Million Liras to 24 Million Liras, G4 from 73 to 9, G5 from 80 to 26, G6 from 33 to 21, G7 from 1.772 to 1.647; but $\mathrm{C} 1$ should be increased from 98 to 157 .

In table 8 there are reference sets of inefficient agencies according to input and output oriented CCR and BCC. For example, an agency which operating in TR21 region and needs to reach efficiency score of "1" within the scope of output oriented CCR analysis so that it has to take agencies located in regions TR41, TR90 and TR63 as reference. As TR21 is efficient according to input and output oriented BCC, there is no need for agency in TR21 region to take any agencies as reference. Similar interpretations can be done according to reference sets in table for other inefficient agencies as well. Agencies in regions TR41 and TR63 have the most references. 
Yayın Gelis Tarihi: $\quad$ 12.05.2016

Yayın Kabul Tarihi: $\quad 04.04 .2017$

Online Yayın Tarihi: 04.12.2017

Dokuz Eylül Üniversitesi

Cilt:32, Sayl:2, Yll:2017, ss 47-78

Table 7.Potential Improvements of Inefficient Agencies according to Input Oriented CCR and BCC

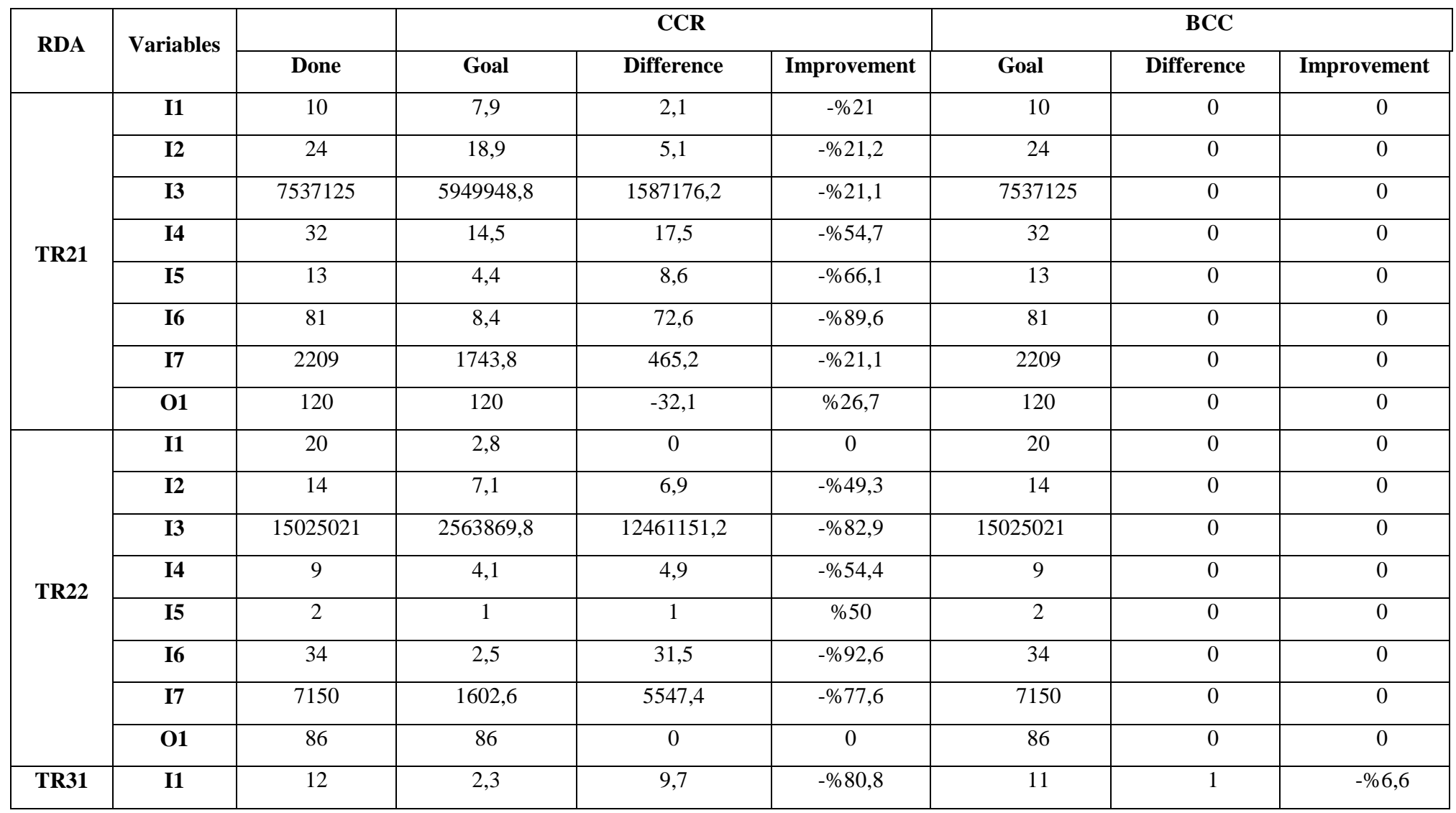


R.TARI -F.PEHLIVANOĞLU -M.ÖZBILLGIN

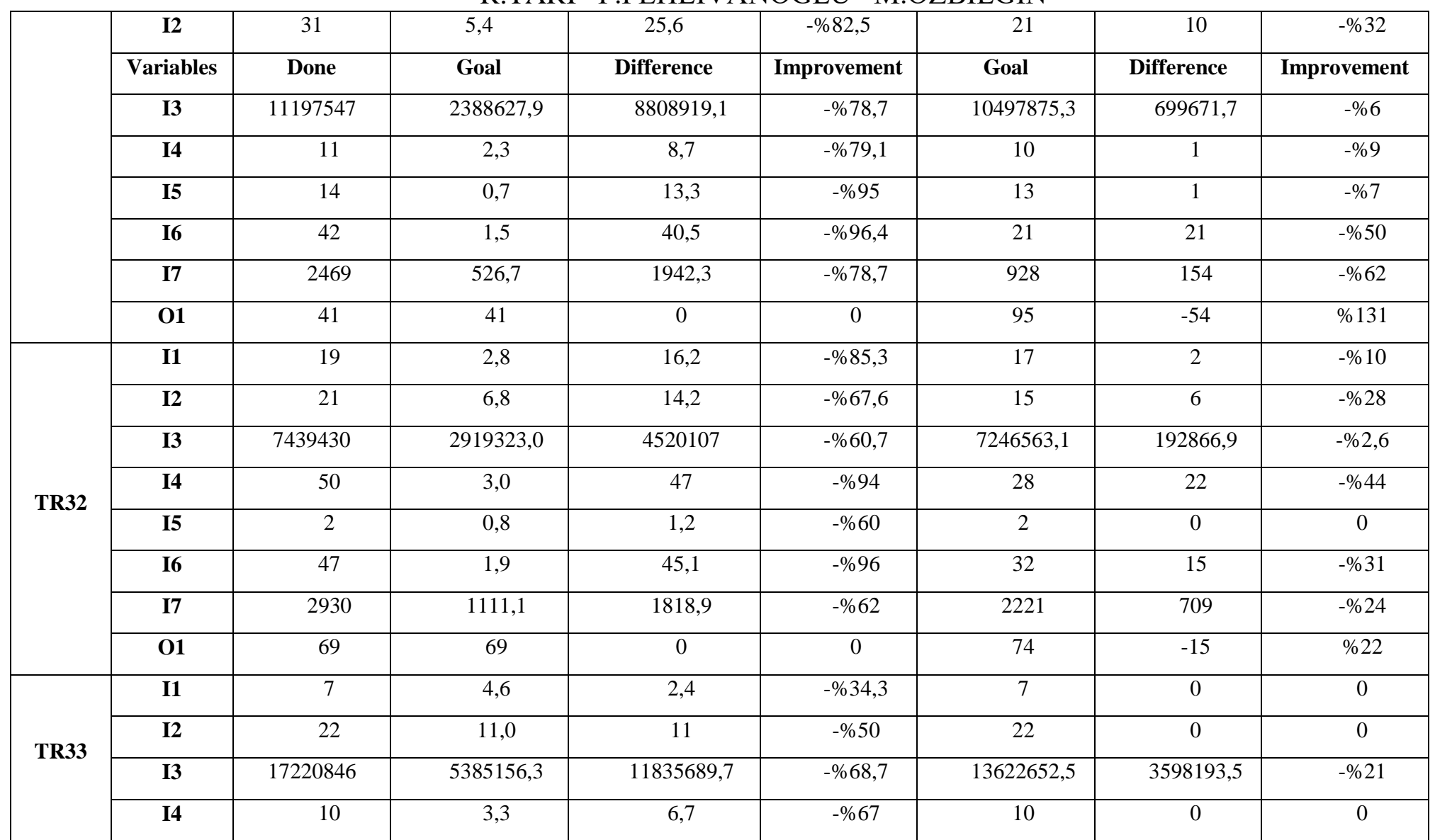


Dokuz Eylül Üniversitesi İktisadi ve İdari Bilimler Fakültesi Dergisi

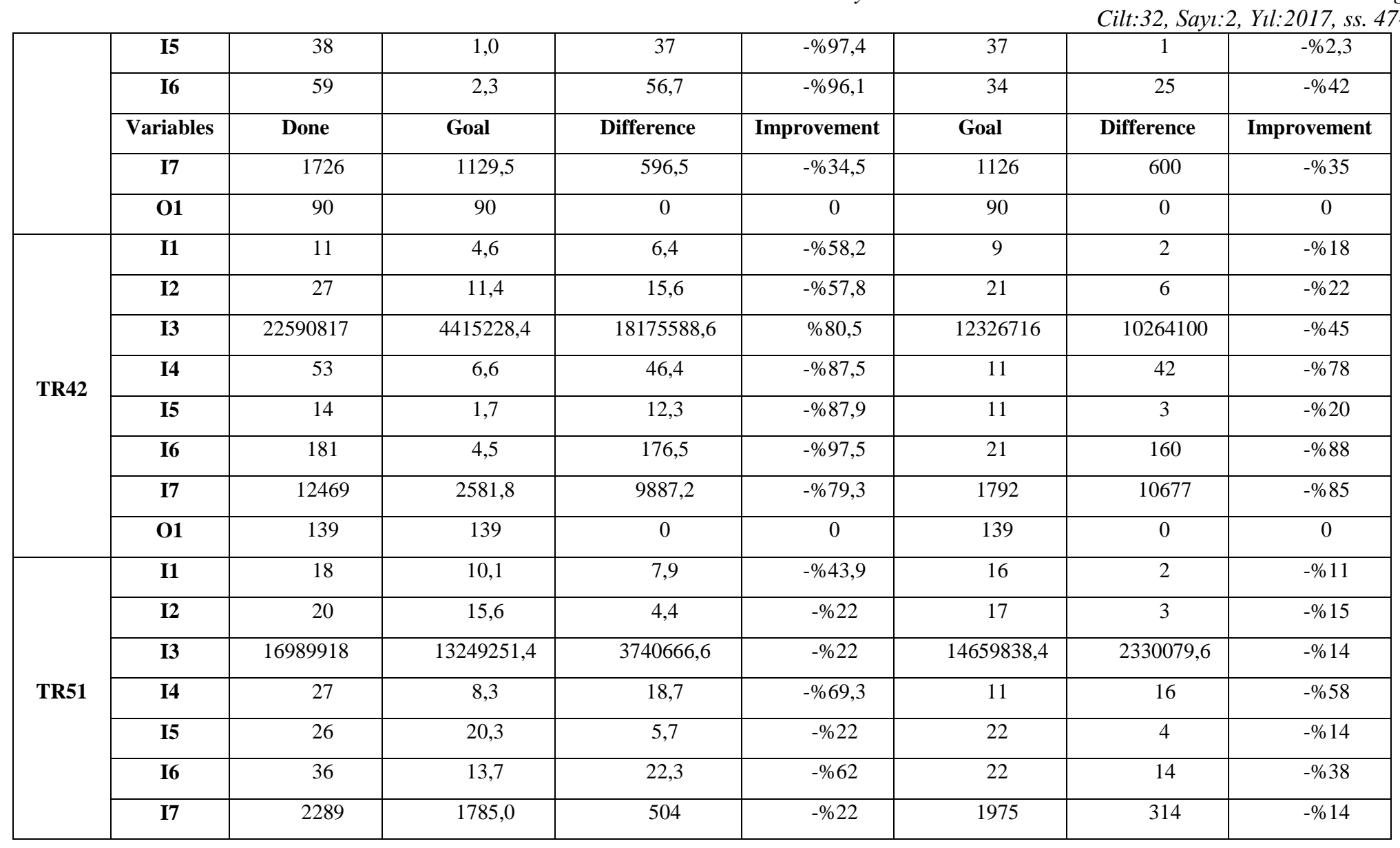


R.TARI -F.PEHLIVANOĞLU -M.ÖZBILLIIN

\begin{tabular}{|c|c|c|c|c|c|c|c|c|}
\hline & 01 & 151 & 151 & 0 & 0 & 151 & 0 & 0 \\
\hline \multirow{7}{*}{ TR61 } & I1 & 18 & 7,8 & 10,2 & $-\% 56,7$ & 18 & 0 & 0 \\
\hline & I2 & 23 & 18,4 & 4,6 & $-\% 20$ & 23 & 0 & 0 \\
\hline & I3 & 8450699 & 713431,3 & 1316385,7 & $-\% 15,6$ & 8450699 & 0 & 0 \\
\hline & I4 & 13 & 11,0 & 2 & $-\% 15,4$ & 13 & 0 & 0 \\
\hline & I6 & 31 & 6,5 & 24,5 & $-\% 79$ & 31 & 0 & 0 \\
\hline & I7 & 1258 & 1062,0 & 196 & $-\% 15,6$ & 1258 & 0 & 0 \\
\hline & 01 & 102 & 102 & 0 & 0 & 102 & 0 & 0 \\
\hline \multirow{5}{*}{ TR62 } & I1 & 19 & 10,2 & 8,8 & $-\% 46,3$ & 13 & 6 & $-\% 31$ \\
\hline & I5 & 8 & 5,7 & 2,3 & $-\% 28,7$ & 7 & 1 & $-\% 12$ \\
\hline & I6 & 35 & 13,9 & 21,1 & $-\% 60,3$ & 17 & 18 & $-\% 51$ \\
\hline & I7 & 1174 & 830,3 & 343,7 & $-\% 29,3$ & 1029 & 145 & $-\% 12$ \\
\hline & 01 & 114 & 114 & 0 & 0 & 141 & -27 & $\% 24$ \\
\hline \multirow{2}{*}{ TR71 } & I1 & 17 & 3,0 & 14 & $-\% 82,3$ & 17 & 0 & 0 \\
\hline & I2 & 15 & 7,2 & 7,8 & $-\% 52$ & 15 & 0 & 0 \\
\hline
\end{tabular}


Dokuz Eylül Üniversitesi İktisadi ve İdari Bilimler Fakültesi Dergisi

\begin{tabular}{|c|c|c|c|c|c|c|c|c|}
\hline & & & & \multicolumn{5}{|c|}{ Cilt:32, Sayl:2, Yll:2017, ss. 47} \\
\hline & $\mathbf{I 5}$ & 2 & 1,0 & 1 & $-\% 50$ & 2 & 0 & 0 \\
\hline & I6 & 34 & 2,2 & 31,8 & $-\% 93,5$ & 34 & 0 & 0 \\
\hline & Variables & Done & Goal & Difference & Improvement & Goal & Difference & Improvement \\
\hline \multirow{6}{*}{ TR72 } & I1 & 14 & 6,7 & 7,3 & $-\% 52,1$ & 13 & 1 & $-\% 7$ \\
\hline & $\mathbf{I} 2$ & 22 & 13,1 & 8,9 & $-\% 40,5$ & 20 & 2 & $-\% 9$ \\
\hline & $\mathbf{I 3}$ & 15893545 & 9462480,7 & 6431064,3 & $-\% 40,5$ & 14434222,9 & 1459322,1 & $-\% 9$ \\
\hline & I4 & 4 & 2,4 & 1,6 & $-\% 40$ & 4 & 0 & 0 \\
\hline & I7 & 2322 & 614,3 & 1707,7 & $-\% 73,5$ & 629 & 1693 & $-\% 73$ \\
\hline & 01 & 90 & 90 & 0 & 0 & 112 & -22 & $\% 24$ \\
\hline \multirow{5}{*}{ TR81 } & I1 & 6 & 4,7 & 1,3 & $-\% 21,7$ & 6 & 0 & 0 \\
\hline & 12 & 22 & 11,3 & 10,7 & $-\% 48,6$ & 22 & 0 & 0 \\
\hline & I3 & 8952004 & 5690133,3 & 3261870,7 & $-\% 36,4$ & 8952004 & 0 & 0 \\
\hline & I4 & 16 & 3,1 & 12,9 & $\% 80,6$ & 16 & 0 & 0 \\
\hline & I5 & 19 & 0,9 & 18,1 & $-\% 95,3$ & 19 & 0 & 0 \\
\hline
\end{tabular}


R.TARI -F.PEHLIVANOĞLU -M.ÖZBILLGIN

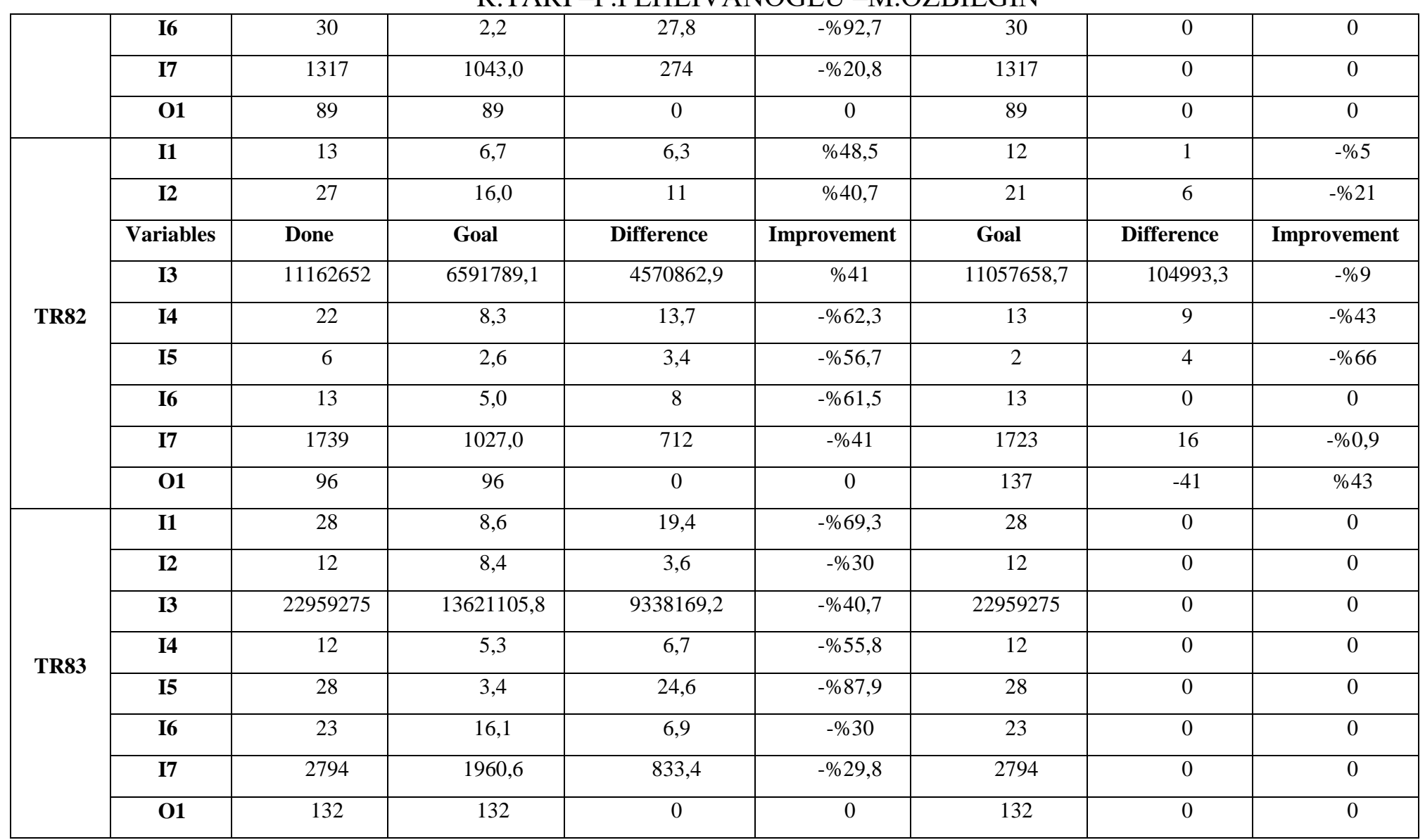


Dokuz Eylül Üniversitesi İktisadi ve İdari Bilimler Fakültesi Dergisi

\begin{tabular}{|c|c|c|c|c|c|c|c|c|}
\hline & & & & \multicolumn{5}{|c|}{ Cilt:32, Sayl:2, Yll:2017, ss. 47} \\
\hline \multirow{6}{*}{ TRA1 } & $\mathbf{I 2}$ & 20 & 9,1 & 10,9 & $-\% 54,5$ & 15 & 5 & $-\% 25$ \\
\hline & I4 & 55 & 8,8 & 46,2 & $-\% 84$ & 25 & 30 & $-\% 54$ \\
\hline & I5 & 96 & 32,6 & 63,4 & $-\% 66$ & 36 & 60 & $-\% 62$ \\
\hline & Variables & Done & Goal & Difference & Improvement & Goal & Difference & Improvement \\
\hline & I7 & 2684 & 1228,5 & 1455,5 & $-\% 54,2$ & 1930 & 754 & $-\% 28$ \\
\hline & 01 & 95 & 95 & 0 & 0 & 96 & -1 & $\% 1$ \\
\hline \multirow{6}{*}{ TRA2 } & I1 & 26 & 4,2 & 21,8 & $-\% 83,8$ & 26 & 0 & 0 \\
\hline & I2 & 9 & 5,1 & 3,9 & $-\% 43,3$ & 9 & 0 & 0 \\
\hline & I5 & 21 & 1,8 & 19,2 & $-\% 91,4$ & 21 & 0 & 0 \\
\hline & I6 & 81 & 7,7 & 73,3 & $-\% 90,5$ & 81 & 0 & 0 \\
\hline & I7 & 5317 & 1416,3 & 3900,7 & $-\% 73,3$ & 5317 & 0 & 0 \\
\hline & 01 & 82 & 82 & 0 & 0 & 82 & 0 & 0 \\
\hline \multirow{3}{*}{ TRB1 } & I1 & 26 & 4,8 & 21,2 & $-\% 81,5$ & 26 & 0 & 0 \\
\hline & I2 & 19 & 10,5 & 8,5 & $-\% 44,7$ & 19 & 0 & 0 \\
\hline & I3 & 9769996 & 5386846,5 & 4383149,5 & $-\% 44,9$ & 9769996 & 0 & 0 \\
\hline
\end{tabular}


R.TARI -F.PEHLIVANOĞLU -M.ÖZBILLIIN

\begin{tabular}{|c|c|c|c|c|c|c|c|c|}
\hline & I4 & 9 & 5,0 & 4 & $-\% 44,4$ & 9 & 0 & 0 \\
\hline & I5 & 11 & 1,5 & 9,5 & $-\% 86,4$ & 11 & 0 & 0 \\
\hline & I6 & 90 & 4,5 & 85,5 & $-\% 95$ & 90 & 0 & 0 \\
\hline & 01 & 114 & 114 & 0 & 0 & 114 & 0 & 0 \\
\hline \multirow{5}{*}{ TRB2 } & I1 & 27 & 2,3 & 24,7 & $-\% 91,5$ & 27 & 0 & 0 \\
\hline & Variables & Done & Goal & Difference & Improvement & Goal & Difference & Improvement \\
\hline & $\mathbf{I 3}$ & 7461431 & 2841304,6 & 4620126,4 & $-\% 61,9$ & 7461431 & 0 & 0 \\
\hline & I4 & 15 & 2,1 & 12,9 & $-\% 86$ & 15 & 0 & 0 \\
\hline & I5 & 6 & 2,3 & 3,7 & $-\% 61,7$ & 6 & 0 & 0 \\
\hline \multirow{6}{*}{ TRC1 } & I1 & 4 & 2,6 & 1,4 & $-\% 35$ & 4 & 0 & 0 \\
\hline & I2 & 23 & 6,3 & 16,7 & $-\% 72,6$ & 23 & 0 & 0 \\
\hline & I3 & 14592050 & 2874271,8 & 11717778,2 & $-\% 80,3$ & 14592050 & 0 & 0 \\
\hline & I4 & 10 & 2,3 & 7,7 & $-\% 77$ & 10 & 0 & 0 \\
\hline & I5 & 78 & 0,6 & 77,4 & $-\% 99,2$ & 78 & 0 & 0 \\
\hline & I6 & 55 & 1,5 & 53,5 & $-\% 97,3$ & 55 & 0 & 0 \\
\hline
\end{tabular}


Dokuz Eylül Üniversitesi İktisadi ve İdari Bilimler Fakültesi Dergisi

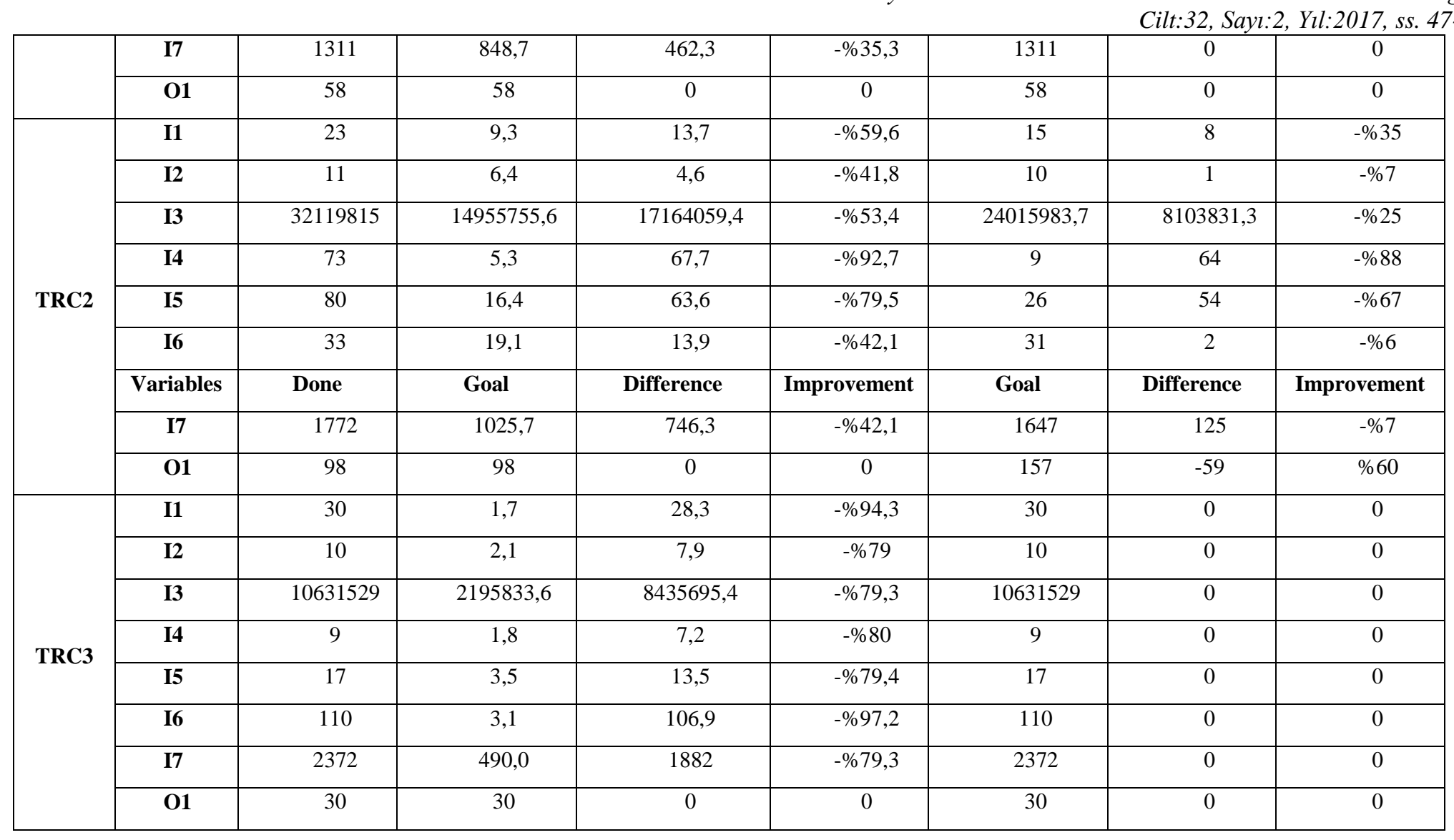


Yayın Geliş Tarihi: $\quad$ 12.05.2016 Yayın Kabul Tarihi: $\quad$ 04.04.2017 Online Yayın Tarihi: 04.12.2017
Dokuz Eylül Üniversitesi İktisadi ve İdari Bilimler Fakültesi Dergisi Cilt:32, Sayl:2, Yll:2017, ss. 47-78

Table 8. Reference Sets of Inefficient Agencies According to Input and Output Oriented $\mathrm{CCR}$ and $\mathrm{BCC}$

\begin{tabular}{|c|c|c|c|c|}
\hline RDA & $\begin{array}{l}\text { Input-oriented } \\
\text { CCR }\end{array}$ & $\begin{array}{l}\text { Input-oriented } \\
\text { BCC }\end{array}$ & $\begin{array}{l}\text { Output- } \\
\text { oriented CCR }\end{array}$ & $\begin{array}{l}\text { Output-oriented } \\
\text { BCC }\end{array}$ \\
\hline TR21 & TR41, TR90, TR63 & TR21 & $\begin{array}{ll}\text { TR41, } & \text { TR90, } \\
\text { TR63 } & \\
\end{array}$ & TR21 \\
\hline TR22 & TR63 & TR22 & TR63 & TR22 \\
\hline TR31 & TR90, TR41, TR63 & $\begin{array}{l}\text { TR61, TR41, } \\
\text { TR81, TR63 }\end{array}$ & $\begin{array}{ll}\text { TR41, } & \text { TR51, } \\
\text { TR63 } & \\
\end{array}$ & $\begin{array}{l}\text { TR41, TR61, TR21, } \\
\text { TR90, TR63 }\end{array}$ \\
\hline TR32 & TR41, TR63 & TR41, TR71 & TR41, TR63 & TR63, TR41, TR71 \\
\hline RDA & $\begin{array}{l}\text { Input-oriented } \\
\text { CCR }\end{array}$ & $\begin{array}{l}\text { Input-oriented } \\
\text { BCC }\end{array}$ & $\begin{array}{l}\text { Output- } \\
\text { oriented CCR }\end{array}$ & $\begin{array}{l}\text { Output-oriented } \\
\text { BCC }\end{array}$ \\
\hline TR33 & TR63, TR41 & $\begin{array}{ll}\text { TR41, } & \text { TRC1, } \\
\text { TR81, } & \text { TR10, } \\
\text { TR63 } & \\
\end{array}$ & TR63, TR41 & $\begin{array}{l}\text { TR10, TR41, TR81, } \\
\text { TR63, TRC1 }\end{array}$ \\
\hline TR42 & TR10, TR63 & $\begin{array}{l}\text { TR41, TR81, } \\
\text { TR10, TR63 }\end{array}$ & TR63, TR10 & TRC1, TR63, TR10 \\
\hline TR51 & $\begin{array}{l}\text { TR41, TR10, TR52, } \\
\text { TR63 }\end{array}$ & $\begin{array}{ll}\text { TRB2, } & \text { TR71, } \\
\text { TR41, } & \text { TR10, } \\
\text { TR52 } & \\
\end{array}$ & $\begin{array}{l}\text { TR41, TR10, } \\
\text { TR52, TR63 }\end{array}$ & $\begin{array}{l}\text { TR41, TR10, TR52, } \\
\text { TR63 }\end{array}$ \\
\hline TR61 & TR90, TR63, TR41 & TR61 & $\begin{array}{l}\text { TR90, TR63, } \\
\text { TR41 }\end{array}$ & TR61 \\
\hline TR62 & TR41, TR10, TR52 & $\begin{array}{ll}\text { TR52, } & \text { TR41, } \\
\text { TR10 } & \end{array}$ & $\begin{array}{l}\text { TR41, } \\
\text { TR52 }\end{array}$ & $\begin{array}{l}\text { TR41, TR52, TR63, } \\
\text { TR10 }\end{array}$ \\
\hline TR71 & $\begin{array}{l}\text { TR10, TR41, TR52, } \\
\text { TR63 }\end{array}$ & TR71 & $\begin{array}{l}\text { TR10, } \quad \text { TR41, } \\
\text { TR52, TR63 }\end{array}$ & TR71 \\
\hline TR72 & TR10, TR41, TR63 & $\begin{array}{l}\text { TR81, TRC3, } \\
\text { TR41, TR10 }\end{array}$ & $\begin{array}{ll}\text { TR10, } & \text { TR41, } \\
\text { TR63 }\end{array}$ & TR10, TR41, TR63 \\
\hline TR81 & TR41, TR63 & TR81 & TR41, TR63 & TR81 \\
\hline TR82 & TR41, TR90, TR63 & \begin{tabular}{ll|} 
TR63, & TR71, \\
TR41 & \\
\end{tabular} & $\begin{array}{ll}\text { TR41, } & \text { TR90, } \\
\text { TR63 } & \\
\end{array}$ & $\begin{array}{l}\text { TR61, TR41, TR71, } \\
\text { TR90, TR63 }\end{array}$ \\
\hline TR83 & TR63, TR41, TR10 & TR83 & $\begin{array}{l}\text { TR41, TR63, } \\
\text { TR10 }\end{array}$ & TR83 \\
\hline TRA1 & TR41, TR52, TR63 & $\begin{array}{l}\text { TR52, TR10, } \\
\text { TR81, TR71 }\end{array}$ & $\begin{array}{ll}\text { TR41, } & \text { TR52, } \\
\text { TR63 } & \\
\end{array}$ & TR41, TR52, TR63 \\
\hline TRA2 & TR10, TR63 & TRA2 & TR10, TR63 & TRA2 \\
\hline TRB1 & TR10, TR41, TR63 & TRB1 & $\begin{array}{ll}\text { TR10, } & \text { TR41, } \\
\text { TR63 }\end{array}$ & TRB1 \\
\hline TRB2 & $\begin{array}{l}\text { TR10, TR41, TR52, } \\
\text { TR63 }\end{array}$ & TRB2 & $\begin{array}{l}\text { TR10, TR41, } \\
\text { TR52, TR63 }\end{array}$ & TRB2 \\
\hline TRC1 & TR41, TR63 & TRC1 & TR41, TR63 & TRC1 \\
\hline TRC2 & TR41, TR52, TR10 & $\begin{array}{l}\text { TR52, } \\
\text { TR10 } \\
\end{array}$ & $\begin{array}{ll}\text { TR41, } & \text { TR52, } \\
\text { TR10 }\end{array}$ & $\begin{array}{l}\text { TR41, TR52, TR10, } \\
\text { TR63 }\end{array}$ \\
\hline TRC3 & $\begin{array}{l}\text { TR41, TR52, TR10, } \\
\text { TR63 }\end{array}$ & TRC3 & $\begin{array}{l}\text { TR41, } \text { TR10, } \\
\text { TR52, TR63 }\end{array}$ & TRC3 \\
\hline
\end{tabular}




\section{CONCLUSION}

To cater for national development from the heart of it and multi dimensionally, regional development agencies were established. The aim is to compensate for regional development differences and to support local and regional entrepreneurship. It has been more than 5 years since RDAs have been established in Turkey. However, there are still differences between countryside and cities in terms of developmental level so that speeding up regional development continues to be one of the major priorities. Reasons such as economic and social convergence with EU and alignment with acquis increase importance of development agencies for the country. Moreover, agencies' duties and authorities, financial resources, relationships with central and local management, corporate identities, legal, administrative and financial structures and operations bring many arguments with them. For that matter, it is important to reveal that how efficient in agencies produce quality service and how efficient they fulfill the function that they are expected to.

With this study efficiency measurements of RDA which operates in Turkey were done for the year 2012. Results obtained from the study are expected to be resources for finding new strategies for managers of agencies. DEA is preferred in efficiency measurements due to having similar input - output structure and same goals with RDA. DEA is a quantitative method that is based on measuring performances of decision units relatively and calculating technical efficiencies. At the end of the analysis done with CCR and BCC models agencies' current values and target values are defined and it is found out that to make them more efficient which input will be decreased and which output will be increased. With the help of input oriented DEA these values are calculated; RDA's average efficiency value for CCR model 0,649 and for BCC model 0,961, scale efficiency 0,673. On the other hand, by using output oriented DEA these values are calculate; RDA's average efficiency value for CCR model 0,649 , for BCC model 0,855 ; scale efficiency 0,785 so that agency operated efficiently. Consequently, among 26 analyzed RDAs for CCR model only 5 are efficient while this number is 16 for 


\section{R.TARI -F.PEHLIVANOĞLU -M.ÖZBİLGIN}

BCC model which shows agencies are not operating efficiently in Turkey. Agencies in regions TR10, TR41, TR52, TR63 and TR90 showed the best performances; but in CCR analysis agencies in regions TRC3, TR31, TRB2, TR32 and TR42; in BCC analysis agencies in regions TR31, TR42, TRA1, TRC2 and TR72 showed insufficient performances.

It's important to direct RDA to productive fields in order to make it both economically and technically efficient. Agencies need to increase their popularity and their operations need to be widespread in order to support projects that provide efficient solutions to financial problems. Developing humane, technical and institutional capacities is another aspect that have indirect effect on RDA's efficiency. In this context, it is thought that training programs for staff working at agencies would be effective from the aspect of professional experience. Development agencies should cooperate and share information-experience with various institutions especially universities and agencies in other regions.

Obtained results within the scope of DEA are periodic and limited with variable set which is used. Change in solved models' results can be observed in detail by using different input-output sets at different times. In future studies, DEA can be more comprehensive by adding different variables to analysis such as agency capacity, service quality, success of supported projects and contributions to economy.

\section{REFERENCES}

ADLER, N., FRIEDMAN, L., SINUANY-STERN, Z. (2002), "Review of Ranking Methods in the Data Envelopment Analysis Context", European Journal of Operational Research, 140, 249-265.

ANSELL, C. (2000), "The Networked Polity: Regional Development in Western Europe", Governance, 13(3), 303-333. 
BACHTLER, J. and YUILL, D. (2001), "Policies and Strategies for Regional Development: A Shift in Paradigm?", Regional and Industrial Policy Research Paper, Number: 46, European Policies Research Centre, UK.

BANKER, R. D., CHARNES, A., and COOPER, W. W. (1984), "Some Models for Estimating Technical and Scale Efficiencies in Data Envelopment Analysis," Management Science, 30(9), 1078-1092.

CHARNES, A., COOPER, W.W., RHODES, E. (1978), "Measuring the Efficiency of Decision Making Units," European Journal of Operational Research, 2, 429-444.

COOPER, W. W., SEIFORD, L. M., and TONE, K. (2007), Introduction to Data Envelopment Analysis and Its Uses: With DEA-Solver Software and References, Springer, New York.

DDK (2014), Türkiye'nin Kalkınma Ajansları Uygulamasının Değerlendirilmesi, T.C. Cumhurbaşkanlığı Devlet Denetleme Kurulu Araştırma ve İnceleme Raporu, 2014/3.

FARRELL, M. J. (1957), "The Measurement of Productive Efficiency", Journal of the Royal Statistical Society, 120(3), 253-281.

HALKIER, H., DANSON, M., DAMBORG, C. (1998), Regional Development Agencies in Europe, Jessica Kingsley. London.

KEATING, M.1 (2004), "The Political Economy of Regionalism", (Eds. Michael Keating, John Loughin), The Political Economy of Regionalism , 17-40, Routledge, UK.

MAILLAT, D. (1998), Interactions Between Urban Systems and Localized Productive Systems: An Approach to Endogenous Regional Development in Terms of Innovative Milieu, European Planning Studies, 6(2), 117-129.

MOUNTFORD, D. (2009), Organising for Local Development: The Role of Local Development Agencies, Summary Report, CFE/LEED(2009)18. 


\section{R.TARI -F.PEHLIVANOĞLU -M.ÖZBİLGIN}

RAO, H. and BABU, M. D. (1996), "Intra-Regional Disparities In HyderabadKarnataka Region: An Analysis", Regional Development: Problems and Policy Measures, (Ed. A. Aziz and S. Krishna), Concept Publishing Company, New Delhi.

SADIQ, S. (2011), "The Final Frontier: A SAS Approach to Data Envelopment Analysis”, in SAS Global Forum 2011 Operations Research, Paper, 198-2011.

STIMSON, R. J., STOUGH R. R., and ROBERTS B. H. (2006), Regional Economic Development: Analysis and Planning Strategy, Berlin: Springer.

TONE, K. (1996), "A Simple Characterization of Returns to Scale in DEA", Journal of the Operations Research Society of Japan, 39(4), 604-613. 